\title{
Efek Asam Alfa Lipoat pada Kadar MDA dan Histologi Ginjal Tikus Wistar Diabetes Melitus Tipe 1
}

\section{Effect of Alpha Lipoic Acid on MDA Levels and Histology of Wistar Rats' Kidney Type 1 Diabetes Mellitus}

\author{
Novita Fahrianti $P^{1}$, Diana Lyrawati ${ }^{2}$, Imam Sarwono ${ }^{3}$ \\ ${ }^{1}$ Program Studi Farmasi Fakultas Kedokteran Universitas Brawijaya Malang \\ ${ }^{2}$ Laboratorium Farmasi Fakultas Kedokteran Universitas Brawijaya Malang \\ ${ }^{3}$ Laboratorium Patologi Anatomi Fakultas Kedokteran Universitas Brawijaya Malang
}

\begin{abstract}
ABSTRAK
Asam alfa lipoat (ALA) telah banyak digunakan dalam pencegahan dan mengatasi komplikasi diabetes akibat spesies oksigen reaktif (ROS). Penelitian ini bertujuan untuk membuktikan bahwa ALA dapat mencegah peningkatan stres oksidatif pada ginjal tikus diabetes mellitus (DM) tipe 1. Penelitian eksperimental menggunakan Post Test Only Control Group dilakukan terhadap 30 tikus Wistar jantan. Sampel dipilih secara acak ke dalam kelompok normal (NTA), DM (DTA), DM dengan terapi per oral ALA 80 (DA80), 200 (DA200), dan 500 (DA500) mg/kg berat badan/hari. Variabel yang diukur pada penelitian ini adalah kadar malondialdehid (MDA) yang diukur dengan spektrofotometri, bobot dan histologi ginjal dengan pewarnaan hematoksilin dan eosin. Hasil penelitian menunjukkan bahwa kadar malondialdehid tertinggi ialah pada kelompok DA80 $(45,500 \pm 9,4538 ; p=0,870)$ dan rasio bobot ginjal/berat badan tertinggi ialah pada kelompok DA200 $(0,013 \pm 0,0060 ; p=0,537)$ namun secara statistika hasilnya tidak bermakna. Pengamatan histologi pada glomerulus ginjal menunjukkan adanya kerusakan (pembentukan stroma dan pengecilan ukuran inti sel) pada kelompok DTA, DA80, DA200, dan DA500. Kesimpulan dari penelitian ini adalah pemberian ALA per oral dalam waktu empat minggu tidak bisa menurunkan stres oksidatif maupun memperbaiki histologi ginjal pada DMT1, bahkan memperburuk gambaran histologi ginjal.
\end{abstract}

Kata Kunci: Asam alfa lipoat, DM1,histologi ginjal, malondialdehid

\section{ABSTRACT}

Alpha lipoic acid has been widely used in the prevention and management of diabetes complications caused by reactive oxygen species (ROS). This study aims to prove that ALA may prevent an increase in oxidative stress in the rats' kidney type 1 diabetes mellitus. Experimental studies used Post Test Only Control Group carried out on 30 male Wistar rats. Samples were assigned randomly into normal (NTA), DM (DTA), DM with therapy of ALA 80 (DA80), 200 (DA200), and 500 (DA500) $\mathrm{mg} / \mathrm{kgBW} / \mathrm{d}$ per oral. The variables measured in this study were the levels of malondialdehyde (MDA) by using spectrophotometry, kidney weights and histology stained with hematoxylin and eosin. The results show that the highest MDA level was in DA80 $(45,500 \pm 9,4538 ; p=0,870)$ and highest ratio of kidney weight/body weight was in DA200 $(0,013 \pm 0,0060 ; p=0,537)$ but statistically not significant. Histological observation on the renal glomerulus showed defects (development of stroma and shrinkage of cells nuclei) in DTA, DA80, DA200, and DA500 groups. This study concludes that the oral administrations of ALA for 4 weeks neither decrease oxidative stress nor improve kidney histology in T1DM, but worsen the histological profiles of kidney.

Keywords: Alpha lipoic acid, DM1, kidney histology, malondialdehyded

Jurnal Kedokteran Brawijaya, Vol. 28, No. 3, Februari 2015; Korespondensi: Diana Lyrawati. Laboratorium Farmasi Fakultas Kedokteran Universitas Brawijaya Malang, Jl. Veteran Malang Tel.(0341)566117Email:eldi_7_98@yahoo.com 


\section{PENDAHULUAN}

Diabetes melitus merupakan sekelompok gangguan metabolik yang ditandai dengan hiperglikemia (1). Hiperglikemia dapat meningkatkan produksi radikal bebas terutama spesies oksigen reaktif (ROS) (2). Dalam kondisi normal, ROS akan berperan dalam proliferasi sel dan kekebalan tubuh. Disisi lain kadar ROS yang berlebihan dapat menyebabkan kerusakan dan kematian sel (3).

Pada pasien diabetes, terjadi peningkatan peroksidasi lipid akibat peningkatan produksi radikal bebas yang menjadi penyebab utama terjadinya komplikasi pada diabetes mellitus (4). Malondialdehid (MDA) merupakan produk sekunder dari peroksidasi lipid setelah terpapar ROS dan radikal bebas yang dapat digunakan sebagai indikator terjadinya kerusakan membran sel (5).

Peningkatan stres oksidatif berperan pada patogenesis terhadap komplikasi yang terjadi karena hiperglikemi, termasuk nefropati. Hiperglikemi perlu diatasi dengan pemberian terapi antioksidan untuk mencegah peningkatan stres oksidatif. Asam alfa lipoat (ALA) telah banyak digunakan dalam pencegahan dan mengatasi komplikasi pada diabetes. Dosis ALA yang digunakan pada penelitian-penelitian sebelumnya berbeda-beda pada setiap organ yang diteliti. Belum ada penetapan dosis ALA yang digunakan untuk mencegah komplikasi pada semua organ. Penelitian ini bertujuan untuk membuktikan bahwa ALA dapat mencegah peningkatan stres oksidatif pada ginjal tikus diabetes mellitus tipe 1 dengan menggunakan tiga macam dosis untuk menilai peningkatan bobot ginjal, kadar MDA, dan perubahan histologi ginjal pada DM tipe 1.

\section{METODE}

\section{Kelompok Penelitian dan Induksi Diabetes}

Subjek yang dipilih pada penelitian ini adalah 30 ekor tikus jantan (Rattus novergicus) galur Wistar, usia 75-90 hari. Penetapan jumlah subjek dihitung dengan rumus Federer dan memperhitungkan mortalita tikus model Diabetes yang mencapai $40 \%$ serta persetujuan Komite Etik FKUB. Subjek dimasukkan ke dalam 5 kelompok yaitu kelompok NTA (normal), DTA (diabetes tanpa ALA), DA80 (diabetes+ALA $80 \mathrm{mg} / \mathrm{kgBB} /$ hari), DA200 (diabetes+ALA $200 \mathrm{mg} / \mathrm{kgBB} / \mathrm{hari}$ ), DA500 (diabetes+ALA $500 \mathrm{mg} / \mathrm{kgBB} /$ hari). Induksi diabetes dilakukan dengan injeksi intraperitoneal streptozotocin dosis tunggal $60 \mathrm{mg} / \mathrm{kg}$ setelah tikus dipuasakan selama \pm 20 jam. Glukosa darah puasa diukur setelah tiga hari injeksi. Penetapan diabetes mellitus jika glukosa darah $>200 \mathrm{mg} /$ dl. Suplemen ALA disiapkan dari serbuk Thioctic Acid (Jiangsu Tohope Pharmaceutical CO., LTD, Changshu, Cina) yang dilarutkan dalam minyak zaitun. ALA diberikan pada kelompok III, IV, dan V selama 28 hari yang dimulai tujuh hari sejak awitan diabetes. Bentuk sediaan dan dosis ALA yang digunakan pada penelitian ini mengacu pada hasil penelitian terdahulu (6). Tikus dikorbankan pada hari ke-29 dan segera diambil darah dari jantung serta dilakukan preparasi histologi ginjal. Semua perlakuan pada hewan coba telah disetujui oleh Komisi Etik Penelitian Kesehatan Fakultas Kedokteran Universitas Brawijaya dengan keterangan kelaikan etik nomor 220/EC KEPK-S1-FARM/03 2014.

\section{Penimbangan Bobot Ginjal}

Penimbangan dilakukan baik untuk berat badan tikus maupun ginjal (KERN 440-33N dengan ketelitian timbangan 0,01 gram).

\section{Pemeriksaan Kadar Malondialdehid (MDA)}

Pemeriksaan kadar MDA berdasarkan reaksi antara MDA dengan molekul Thiobarbituric Acid (TBA). Sampel ginjal yang dihomogenisasi, diambil $10 \mathrm{mg}$ dicampurkan dengan natrium tiobarbiturat $1 \%$, TCA $100 \%$, dan $\mathrm{HCl} 1 \mathrm{~N}$ yang diukur secara spektrofotometri pada $\lambda 532 \mathrm{~nm}$.

\section{Pengamatan Histologi Ginjal}

Pengamatan histologi ginjal baik kiri maupun kanan dilakukan dengan pewarnaan Hematoksilin dan Eosin 1\% dengan ketebalan \pm 3-5 mikron. Jaringan diproses dengan mesin Tissue Tex Processor. Preparat jaringan ginjal kemudian diamati menggunakan mikroskop cahaya perbesaran 200 dan 400 kali dan direkam secara digital. Jumlah stroma dan inti sel glomerulus dihitung dari gambar histologi yang diperoleh.

\section{Analisis Statistika}

Data kadar MDA dan bobot ginjal yang didapatkan disajikan dalam rerata \pm simpangan baku $(S D)$. Analisis data dilakukan dengan menggunakan uji beda Kruskal-Walis, uji korelasi Pearson-Product Moment dan uji antar kelompok Mann-Whitney dengan SPSS versi 20.00 untuk analisis kadar MDA dan bobot ginjal Hasil analisis dikatakan bermakna bila $\mathrm{p} \leq 0,05$.

\section{HASIL}

Analisis statistik data rasio bobot ginjal terhadap berat badan tikus menunjukkan perbedaan rata-rata yang tidak bermakna $(p=0,537)$. Uji korelasi Pearson-Product Moment menunjukan korelasi positif lemah, namun tidak bermakna $(r=0,366, p=0,148)$.

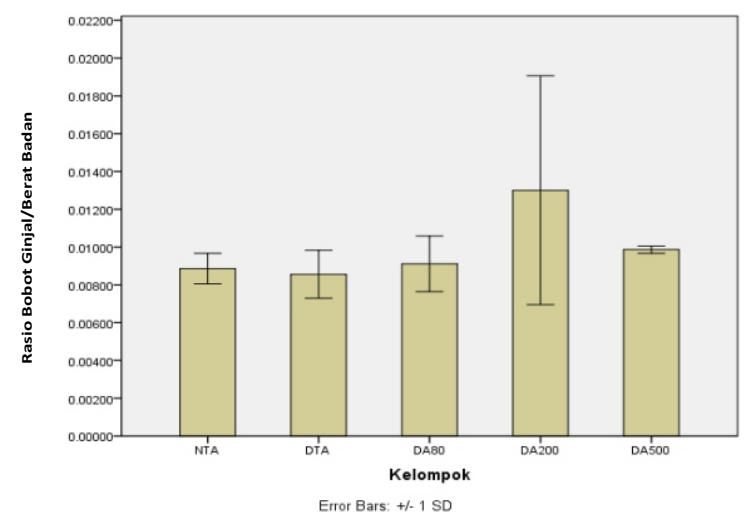

Gambar 1. Grafik batang rasio bobot ginjal terhadap berat badan tikus

Keterangan: Data ditampilkan dalam rerata \pm simpangan baku (SD)

Data rasio bobot ginjal terhadap berat badan dapat dilihat pada Gambar 1. Tikus pada kelompok DA200 menunjukkan rasio bobot ginjal paling tinggi. Rasio bobot ginjal kelompok NTA, DTA, DA80, dan DA500 memiliki ratarata yang tidak jauh berbeda. 


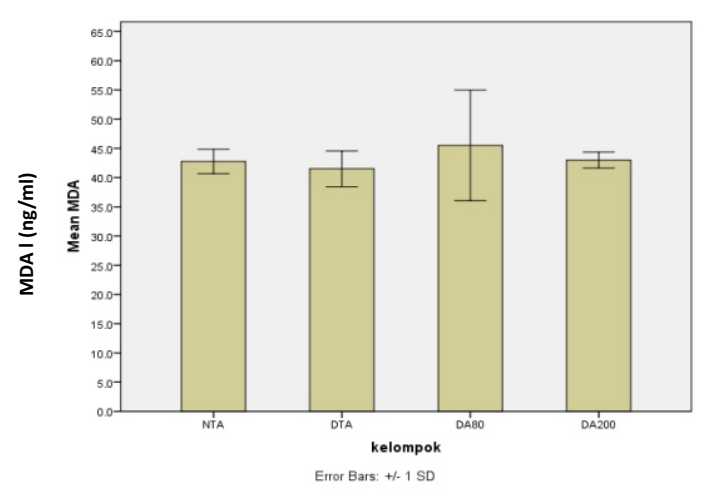

Gambar 2. Grafik Batang Kadar MDA pada Ginjal Tikus Keterangan: Data ditampilkan dalam rerata \pm simpangan baku

Analisis kadar MDA pada ginjal tikus menunjukkan perbedaan rata-rata yang tidak bermakna $(p=0,870)$. Analisis korelasi Pearson-Product Moment menunjukkan korelasi positif yang lemah dan tidak bermakna $(r=0,111$, $p=0,632$ ). Data kadar MDA pada ginjal tikus dapat dilihat pada Gambar 2. Kelompok DA80 memiliki kadar MDA yang paling tinggi, kelompok DTA memiliki kadar MDA yang paling rendah dibandingkan kelompok NTA, DA80, dan DA200, namun secara statistik perbedaan tidak bermakna.

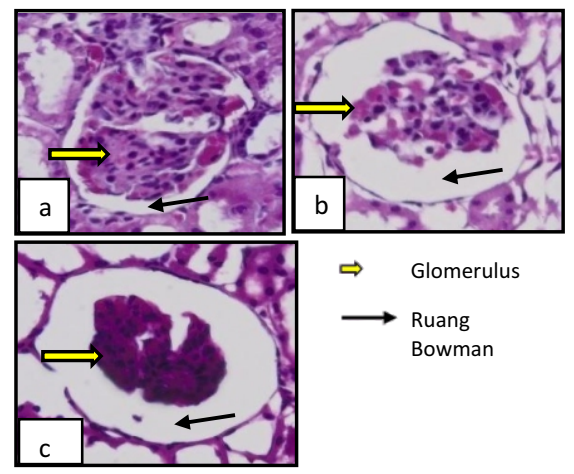

Gambar 3. Struktur glomerulus ginjal tikus NTA

Keterangan: (a) Struktur glomerulus ginjal normal pada tikus kondisi non-diabetes mellitus. (b) dan (c) Struktur glomerulus ginjal tikus nondiabetes mellitus menunjukkan adanya pelebaran ruang Bowman. Perbesaran 400x.

Pengamatan histologi dilakukan pada bagian glomerulus ginjal. Hasil pengamatan histologi pada kelompok NTA menunjukkan adanya pelebaran pada ruang Bowman. Gambaran struktur glomerulus kelompok NTA dapat dilihat pada Gambar 3.
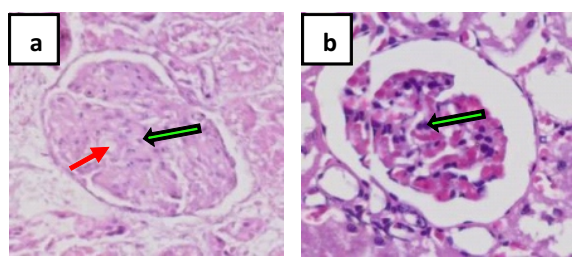

Gambar 4. Struktur glomerulus ginjal tikus diabetes dengan dan tanpa ALA
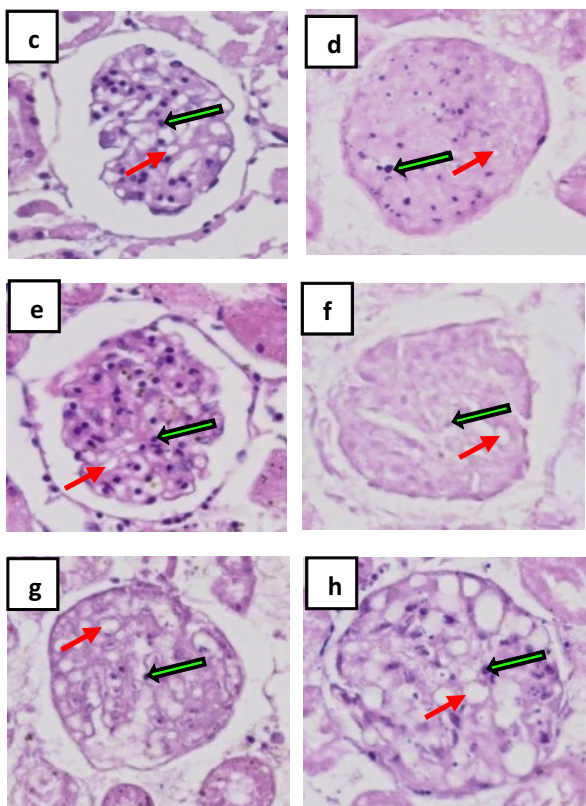

\section{Gambar 4. Struktur glomerulus ginjal tikus diabetes dengan dan tanpa ALA (lanjutan)}

Keterangan:

(a) Struktur glomerulus ginjal tikus kelompok DTA menunjukkan adanya jaringan stroma yang rusak dan pengecilan ukuran inti sel.

(b) Struktur glomerulus ginjal tikus kelompok DTA yang menunjukkan terjadinya pelebaran ruang bowman dan berkurangnya jumlah inti sel.

(c) dan (d) Struktur glomerulus ginjal tikus kelompok DA80 mengalami kerusakan pada jaringan stroma, pelebaran ruang bowman, pengecilan ukuran inti sel, serta berkurangnya jumlah inti sel.

(e) Struktur glomerulus tikus kelompok DA200 menunjukkan adanya jaringan stroma yang rusak, pelebaran ruang Bowman, serta berkurangnya jumlah inti sel.

(f) Struktur glomerulus ginjal tikus kelompok DTA200 mengalami penurunan jumlah inti sel, bahkan hampir tidak ada.

(g) dan (h) Struktur glomerulus ginjal tikus kelompok DA500 menujukkan terjadinya kerusakan pada hampir seluruh jaringan stroma, serta penurunan jumlah inti sel. Tanda panah merah menunjukan jaringan stroma, sedangkan tanda panah hijau inti sel glomerulus. Perbesaran $400 x$.

Hasil pengamatan histologi pada kelompok DTA, DA80, DA200, dan DA500 menunjukkan adanya pelebaran ruang Bowman, jaringan stroma yang rusak, pengecilan ukuran inti sel, serta penurunan jumlah inti sel (Gambar 4). Gambaran histologi glomerulus ginjal pada kelompok NTA menunjukkan pelebaran ruang bowman yang hampir sama dengan kelompok DTA, dan DA80. Gambaran histologi glomerulus pada kelompok DTA, DA80, DA200, dan DA500 menunjukkan kerusakan yang hampir sama.

Pada kelompok DA200 terjadi penurunan jumlah inti sel yang lebih besar dari pada kelompok DTA, DA80, dan DA500. Kelompok DA500 menunjukkan kerusakan pada jaringan stroma yang lebih parah dibandingkan dengan kelompok perlakuan lainnya. Kerusakan jaringan stroma ini dapat dilihat adanya bulatan putih pada glomerulus. Pelebaran ruang bowman pada kelompok DTA dan DA80 menunjukkan pelebaran ruang bowman yang hampir sama dibandingkan dengan kelompok perlakuan lainnya. Pengecilan ukuran inti sel pada kelompok DTA, DA80, DA200, dan DA500 lebih besar dibandingkan pada kelompok NTA. Inti sel pada kelompok NTA yang tidak mendapatkan terapi ALA memiliki ukuran yang lebih besar. Jika dilihat dari jumlah inti, maka kelompok diabetes 
dengan maupun tanpa ALA memiliki jumlah inti lebih sedikit daripada kelompok tikus normal (Tabel 1).

Tabel 1. Jumlah stroma dan inti sel glomerulus tikus normal dan diabetes dengan dan tanpa Asam lipoat Alfa ( $N=4$ glomerulus per preparat kelompok)

\begin{tabular}{ccc}
\hline $\begin{array}{c}\text { Kelompok } \\
\text { Perlakuan }\end{array}$ & $\boldsymbol{\Sigma}$ Stroma & $\boldsymbol{\Sigma}$ Inti Sel \\
\hline NTA & 12 & 237 \\
DTA & 23 & 170 \\
DA80 & 38 & 168 \\
DA200 & 33 & 175 \\
DA500 & 103 & 143 \\
\hline
\end{tabular}

\section{DISKUSI}

Pada kondisi diabetes mellitus, perubahan pertama yang terlihat pada ginjal adalah pembesaran ukuran ginjal dan hiperfiltrasi. Glukosa yang difiltrasi akan direabsorbsi oleh tubulus ginjal dan sekaligus membawa natrium, bersamaan dengan efek insulin yang merangsang reabsorbsi tubuler natrium, sehingga menyebabkan volume ekstrasel meningkat dan terjadilah hiperfiltrasi. Hiperfiltrasi glomerulus pada kondisi diabetes mellitus selalu disertai dengan peningkatan bobot ginjal (7). Pada penelitian ini, kelompok DA200 menunjukkan rasio bobot ginjal lebih tinggi dibandingkan dengan kelompok NTA, DTA, DA80, dan DA500. Hal ini mungkin disebabkan karena hiperfiltrasi glomerulus pada kelompok DA200 lebih tinggi dibandingkan dengan kelompok perlakuan lainnya sehingga peningkatan bobot ginjal juga lebih besar. Pada kelompok perlakuan diabetes yang diterapi dengan ALA selama 4 minggu menunjukkan penurunan bobot ginjal pada dosis $80 \mathrm{mg} / \mathrm{kg}$ berat badan dan $500 \mathrm{mg} / \mathrm{kg}$ berat badan dari pada dosis $200 \mathrm{mg} / \mathrm{kg}$ berat badan, namun hasil uji statistik tidak menunjukkan perbedaan yang bermakna. Hal ini disebabkan karena ALA tidak dapat mencegah peningkatan bobot ginjal yang disebabkan oleh diabetes mellitus. ALA dapat menghambat kerusakan pada ginjal, namun ALA tidak dapat mencegah terjadinya hiperfiltrasi pada glomerulus (9/8).

Pada penelitian ini, kadar MDA pada kelompok DA80 menunjukkan hasil yang lebih tinggi dibandingkan dengan kelompok lainnya. Hal ini menujukkan bahwa stres oksidatif pada kelompok DA80 lebih besar dibandingkan dengan kelompok perlakuan yang lain. Kelompok DTA memiliki kadar MDA lebih rendah dibandingkan kelompok lainnya yang kemungkinan disebabkan karena adanya peningkatan aktivitas antioksidan enzimatis pada ginjal kelompok DTA. Antioksidan enzimatis merupakan antioksidan endogenus yang dapat menghambat pembentukan radikal bebas dengan cara memutuskan reaksi berantai (polimerasi), kemudian mengubahnya menjadi produk yang lebih stabil (10). Pada kelompok DA200 terjadi penurunan kadar MDA dibandingkan kelompok DA80. Hal ini mungkin disebabkan karena ALA pada dosis $200 \mathrm{mg} / \mathrm{kg}$ berat badan memiliki efek antioksidan dalam mengatasi ROS yang lebih baik dibandingkan dengan ALA dosis $80 \mathrm{mg} / \mathrm{kg}$ berat badan, namun berdasarkan hasil analisis statistika perbedaan tersebut tidak bermakna. Hasil yang tidak bermakna ini mungkin disebabkan karena memang pada 4 minggu diabetes belum menunjukkan perbedaan pada aktivitas stres oksidatif, atau stes oksidatif masih dapat dikompensasi oleh homeostasis ginjal. Hsl tersebut juga dapat menjelaskan mengapa ALA tidak terlihat berpengaruh terhadap MDA di ginjal, walaupun mungkin berpengaruh terhadap penanda stres oksidatif yang lain seperti 4-hidroksinenal, isoprostan, 8-hidroksiguanin dan thiaminglikol (9).

Pada histologi ginjal kelompok NTA menunjukkan terjadinya pelebaran pada ruang Bowman seperti pada kelompok perlakuan lainnya. Ruang Bowman adalah ruang di mana filtrat plasma glomeruler dialirkan saat meninggalkan kapiler melalui membran filtrasi $(10,11)$. Pelebaran ruang Bowman ini dapat terjadi akibat tekanan volume urine yang terlalu besar atau glomerulus yang mengecil. Pengecilan glomerulus ginjal juga dapat disebabkan karena terjadi fibrosis pada glomerulus ginjal, namun, ukuran inti sel pada kelompok NTA lebih besar dibandingkan kelompok DTA, DA80, DA200, dan DA500. Jumlah inti sel pada kelompok NTA juga tidak mengalami penurunan jika dibandingkan dengan kelompok perlakuan lainnya. Jaringan stroma pada glomerulus ginjal NTA menujukkan kondisi yang baik dan tidak mengalami kerusakan.

Kelompok DTA menujukkan adanya pelebaran ruang Bowman yang diakibatkan karena tekanan volume urin. Pada kelompok DTA juga terjadi kerusakan pada jaringan stroma dan pengecilan ukuran inti sel. Namun kerusakan jaringan stroma ini tidak begitu parah dibandingkan dengan kelompok DA80, DA200, dan DA500. Hal ini mungkin disebabkan karena adanya peningkatan antioksidan pada tubuh tikus kelompok DTA. Peningkatan antioksidan dapat menghambat aktivasi sel mesangial melalui glukosa darah dan memperbaiki diabetes nefropati (12). Kelompok DA80 dan DA200 menunjukkan adanya pelebaran pada ruang bowman, pengecilan ukuran inti sel, berkurangnya jumlah inti sel, dan Kerusakan pada jaringan stroma. Pada kelompok DA80 nampak bahwa kerusakan yang terjadi pada jaringan stroma lebih besar dibandingkan dengan kelompok DA200 yang ditunjukkan dengan adanya bulatan putih yang lebih besar dan lebih banyak pada glomerulus ginjal kelompok DA80. Hal ini disebabkan karena efektivitas ALA pada dosis $200 \mathrm{mg} / \mathrm{kgBB}$ dapat menghambat kerusakan jaringan yang disebabkan karena oksidatif besi dan dapat meregenerasi vitamin C dan vitamin E dari bentuk teroksidasinya (13). ALA juga bermanfaat sebagai antiinflamasi dengan menghambat aktivasi faktor nuklear кB (NF-kB) (14). Pada kelompok DA500, jaringan stroma yang rusak lebih parah dan penurunan jumlah inti selnya lebih besar. Kerusakan jaringan stroma dapat disebabkan karena adanya penumpukan lemak, protein, atau senyawa lainnya. Hal ini disebabkan karena ALA pada dosis $500 \mathrm{mg} / \mathrm{kgBB}$ tidak dapat mengatasi kerusakan yang disebabkan karena peningkatan stres oksidatif pada kondisi diabetes mellitus dan menyebabkan peningkatan mortalitas.

Kesimpulan dari penelitian ini ialah terapi ALA per oral pada kondisi diabetes mellitus tipe 1 dalam jangka waktu empat minggu tidak dapat menurunkan stres oksidatif pada ginjal. Walaupun pada dosis ALA200mg/kgBB/hari menunjukkan penurunan kadar MDA namun hasilnya tidak bermakna sehingga tidak dapat dijadikan sebagai pedoman terapi tambahan untuk mengatasi stres oksidatif pada ginjal. 


\section{DAFTAR PUSTAKA}

1. Dipiro JT, Talbert RL, Yee JC, Matzke GR, Wells BG, and Posey LM. Pharmacotherapy a Pathophysiologic Approach. 7th ed. New York: The McGraw-Hill Companies; 2008; p. 1206.

2. Mohora M, Greabu M, Muscurel C, Duta C, and Totan A. The Sources and the Targets of Oxidation Stress in the Etiology of Diabetic Complication. Romanian Journal of Biophysics. 2007; 17(2): 63-84.

3. KangralkarVA, Shivraj DP, and Bandivadekar RM. Oxidative Stress and Diabetes: A Review. International Journal of Pharmaceutical Applications. 2010; 1(1): 38-45.

4. Baydas G, Canatan H, and Turkoglu A. Comparative Analysis of the Protective Effect of Melatonin and Vitamin E on Streptozotoci-Induce Diabetes Mellitus. Journal of Pineal Research. 2002; 32(4): 225-230.

5. Kara H, Karatas F, and Canatan H. Effect of Single Dose Cadmium Chloride Administration on Oxidative Stress in Male and Female Rats. Turkish Journal of Veterinary Animal Sciences. 2005; 29: 37-42.

6. Fatmawati N, Lyrawati D, andYurina V. Effect of Alpha Lipoic Acid on Oxidative Stress in Heart of Male Wistar Rats with Type I Diabetes Mellitus Model Induced by Streptozotocin. 6th Asian Association of Schools of Pharmacy Conference Program and Abstracts Book. Singapore, 14-17 November 2013; 183.

7. Wiseman MJ, Saunders AJ, Keen H, and Viberti G. Effect of Blood Glucose Control on Increased Glomerular Filtration Rate and Kidney Size in Insulin-
Dependent Diabetes. The New England Journal of Medicine. 1985; 312(10): 617-621.

8. Melhem MF, Craven PA, Liachenko J, and DeRubertis FR. $\alpha$-Lipoic Acid Attenuated Hyperglycemia and Prevent Glomerular Mesangial Matrix Expansion in Diabetes. Journal of the American Society of Nephrology. 2002; 13(1): 108-116.

9. Mates JM, Cristina P, and Ignacio NC. Antioxidant Enzymes and Human Disease. Clinical Biochemistry. 1999; 32(8): 595-608.

10. Rahmatini. Efek Pemberian Vitamin C terhadap Penurunan Kadar Malondialdehid (MDA) Serum pada Lansia. [Project Report]. Universitas Andalas, Padang. 2010.

11. King D. Histology Study Guide Kidney and Urinary Tract. (Online) 2013. http://www.siumed.edu/ dking2/crr/rnguide.htm. [diakses tanggal 2 April 2014].

12. $\mathrm{Ha} \mathrm{H}$ and Lee HB. Reactive Oxygen Species and Matrix Remodeling in Diabetic Kidney. Journal of the American Society of Nephrology. 2003; 14(8): S246S249.

13. Ying Z, Kampfrath $T$, Sun Q, Parthasarathy S, and Rajagopalan S. Evidence that $\alpha$-lipoic Acid Inhibits NF$\kappa B$ Activation Independent of Its Antioxidant Function. Inflammation Research. 2011; 60(3): 219-225.

14. Kang YJ. Molecular and Cellular Mechanisms of Cardiotoxicity. Environmental Health Perspectives. 2001; 109(1): 27-34. 